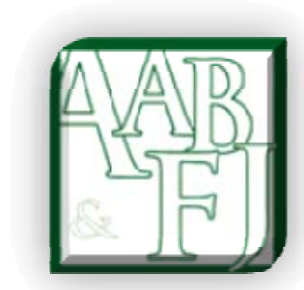

\title{
The Stationarity of South Asian Real Exchange Rates Allowing for Structural Breaks
}

\author{
Ariful Hoque ${ }^{1}$ and Rajabrata Banerjee ${ }^{2}$
}

\begin{abstract}
After the introduction of the nonlinear unit root test in 2003, research has provided evidence of nonlinear real exchange rate dynamics in Asian countries. However, few studies have conducted nonlinear unit root tests for South Asian real exchange rates. Some of these studies argued in favour of stationary real exchange rates, whereas others concluded the nonstationarity of real exchange rates. A major problem with these nonlinear unit root tests is their failure to consider structural changes for long periods of time. To confirm the mixed test results for the stationarity of South Asian real exchange rates, this study employs unit root test by allowing both single and multiple endogenous structural breaks for Bangladesh, India, Pakistan and Sri Lanka for the period of 1957 to 2011, except that data for Bangladesh covers a shorter sample period. Results show nonstationary real exchange rates for the sample countries. Overall empirical evidence indicates that long-run purchasing power parity does not hold for major South Asian countries.
\end{abstract}

JEL Classification: F30, F40

Keywords: stationary, nonlinear, unit root, structural break, purchasing power parity

\footnotetext{
${ }^{1}$ Murdoch University, a.hoque@murdoch.edu.au

${ }^{2}$ University of South Australia, Rajabrata.Banerjee@unisa.edu.au
} 


\section{Introduction}

Purchasing power parity (PPP) relates exchange rates and price levels. It requires that identical goods should be sold under certain conditions for the same price in two different countries at the same time. An extensive literature on PPP theory and its contemporary applications are provided in Officer (1976). For the exchange rate determination, PPP implies that relative exchange rate movement between two countries is detected by the price level differences of those countries. In line with PPP, the real exchange rate can be defined as the nominal exchange rate adjusted by the ratio of the foreign price level to the domestic price level. From definition, it follows that if the difference in price levels between the domestic and foreign country is equivalent to the changes in the nominal bilateral exchange rate, real exchange rate will remain unchanged. Thus, empirically the real exchange rate must be stationary and tends to be mean reverting in order to hold PPP in the long run. However, in the short run most currencies in the past were found to deviate from PPP, both cumulatively and persistently (see Adler \& Lehmann 1983 Genberg 1978; Kravis et al. 1975; Stockman 1980). Consequently, a more accepted fact is that PPP theory is at least invalid in the short run (Artus 1978; Dornbusch 1980; Frenkel 1981; Kravis et al. 1978).

In the empirical literature, the unit root test is widely used to examine the stationarity of the real exchange rate in the long run. Earlier stationary testing procedures, such as the augmented Dickey-Fuller unit root test (ADF) (Dickey \& Fuller 1981) and the PhillipsPerron unit root test (PP) (Phillips \& Perron 1988), have an implicit assumption of a linear time series. The most notable studies that employed these techniques to test unit root on the real exchange rate include studies such as Adler and Lehmann (1983), Corbae and Ouliaris (1991), Edison (1985), Hakkio (1984), Meese and Rogoff (1988) and Roll (1979). Recent developments in this area of study show that real exchange rates are nonlinear. Baum et al. (2001), Micheal et al. (1997), Sarantis (1999) and Taylor et al. (2001) examined the nonlinear properties of real exchange rates. Taylor et al. (2001) found that transaction costs, shipping costs, tariffs and taxes are the possible factors that contribute to nonlinearity in real exchange rates. A few studies extended their research in the line of the nonlinearity real exchange rates of Asian countries. Liew et al. (2003, 2004) and Liew (2004) conducted a series of studies in the Asian region, but South Asia was excluded in their research.

Chowdhury (2004) applied the linearity tests developed by Luukkonnen et al. (1988) and Saikkonen and Luukonen (1988), and found evidence in favour of nonlinearity exhibited in the real exchange rates of Bangladesh. Responding to the plausible presence of nonlinearity in time series, Kapetanios et al. (2003) developed a stationary test, more commonly known as the KPSS unit root test, to examine the null hypothesis of nonstationarity against the alternative of nonlinear stationarity. Ahmad and Rashid (2008) investigated the stationarity of real exchange rates for Bangladesh, India, Pakistan, Sri Lanka and China. They concluded that nonlinear KPSS unit root test provides more evidence in favour of stationary real exchange rates than linear unit root tests, such as ADF or PP Using nonlinear unit root tests in the period 1973-2007, Noman and Rahman (2010) found nonstationary real exchange rates for India, Pakistan and Sri Lanka, whereas their tests results are not conclusive for Bangladesh. Under a nonlinear framework, the limited amount of research on South Asian real exchange rates provided mixed results. This finding means that studies have not achieved a consensus on the stationarity of the real exchange rate. These nonlinear unit root tests do not consider the structural changes required to address time series data, particularly for long periods of time. Perron (1989) showed that failure to allow an existing break leads to bias that reduces the ability to reject a false unit root null hypothesis. 
The current study provides three main contributions to the literature. Firstly, it confirms the nonstationarity of South Asian real exchange rates. It employs the unit root test by allowing both single and multiple endogenous structural breaks for Bangladesh, India, Pakistan and Sri Lanka. Secondly, as Rogoff (1996) showed that PPP deviations die out at a very slow rate, researchers need to use a long-span data set in order to detect mean reversion in the data. This study uses a 55-year sample data period for all countries except Bangladesh. Other similar studies, such as those of Chowdhury (2004) and Noman and Rahman (2010), used 8- and 35-year sample periods, respectively. Thirdly, unlike the work of Noman and Rahman (2010), the present study includes both consumer price index (CPI) and producer price index (PPI) based on non-tradable and tradable goods, respectively. The rest of the paper is organised as follows. Section 2 discusses the methodology and the data used in this paper. Section 3 presents the findings of the stationarity tests. Finally, Section 4 concludes the paper.

\section{Methodology and Data}

The real exchange rate between foreign country $i$ and home country at time $t$ is constructed as follows:

$$
y_{i . t}=s_{i, t} \times \frac{p_{i, t}^{*}}{p_{t}}
$$

where $y_{i, t}$ is the real exchange rate, $s_{i, t}$ is the nominal exchange rate, $p$ is the price level at period $t$ in the home country and $\mathrm{pi}^{*}$ is the price level at period $t$ in the foreign country. Taking logarithms on both sides, eq. (1) can be rewritten as

$$
\mathrm{Y}_{\mathrm{it}}=\mathrm{S}_{\mathrm{it}}+\mathrm{P}_{\mathrm{it}}{ }^{*}-\mathrm{P}_{\mathrm{t}}
$$

where $Y_{\text {it }}$ is the log values of real exchange rate, $S_{i t}$ is the log values of nominal exchange rate, and $\mathrm{P}_{\mathrm{it}}{ }^{*}$ and $\mathrm{P}_{\mathrm{t}}$ are the foreign and domestic price indices in log values, respectively. In this study, the monthly CPI and the monthly PPI values are used to deflate the nominal exchange rates and obtain the real exchange rates. Although it is more common in the literature to use CPI in the calculation of real exchange rates, Obstfeld (2002), Engel (2002) and Bhattacharya et al. (2008) argue that exchange rate pass-through can have different effects on import prices, domestic prices of imported goods, and domestic producer prices. Consequently, both pricing assumptions can be important to reflect changes in domestic price levels to capture inflation in the home country. Moreover, using both deflators to calculate real exchange rates will provide an additional robustness check on the time series properties of data. The CPI mainly includes non-tradable commodities, and PPI in practice includes the prices of the industrial and agricultural sectors, which are categorised as tradable. Gross domestic product deflator is also used among other alternatives, but this series is not available on a monthly basis.

Firstly, the standard ADF and PP tests are employed to identify the presence of unit roots in the real exchange rate (i.e. $Y_{\text {it }}$ of equation 2) without considering the structural changes in the series. The ADF test accommodates serial correlation and time trading by explicitly specifying the autocorrelation structure. The PP test accommodates heteroskedasticity and autocorrelation using the nonparametric method. Phillips and Perron's (1988) research suggests that the PP test has a stronger power than the ADF test under a wide range of circumstances.

Secondly, the unit root test is performed with the Zivot-Andrews (1992) model that determines one structural break point endogenously from the data. Several studies, such as Ben-David et al. (2003), Lumsdaine and Papell (1997) and Maddala and Kim (2003), argued 
that considering only one endogenous break is insufficient and leads to loss of information when actually more than one break exists. Finally, Clemente et al.'s (1998) approach is used to accommodate two endogenous structural breaks for the unit root test. Further, this approach uses Innovation Outliers (IO) and Additive Outlier (AO) models to consider two different forms of structural break. The IO model allows gradual changes, whereas the AO model allows sudden changes in mean (crash model).

In this study, Bangladesh, India, Pakistan and Sri Lanka are used as the sample countries. For the unit root test on real exchange rates for each sample country, the data include (1) the nominal exchange rate against the US dollar, (2) the monthly CPI and the monthly PPI of the US dollar as the foreign price index, and (3) the monthly CPI and the monthly PPI as the domestic price index. Data on nominal exchange rate, CPI and PPI price series for home and foreign countries are downloaded from the 'Datastream' database. In this study, two sets of real exchange rates are used based on monthly CPI and PPI data series. The descriptions of sample data are given in Table 1. In column 4, real exchange rate data set calculated using CPI series shows a sample period of 55 years for all countries except Bangladesh, which starts from 1993 onwards and thus covers a shorter sample period. However, the real exchange rate series calculated using PPI is not same for all countries as shown in the last column which ranges between 35 and 55 years.

Table 1: Data Description

\begin{tabular}{l|c|c|c|c|c|c}
\hline & \multicolumn{2}{|c|}{ Real exchange rates calculated using CPI } & \multicolumn{2}{c}{ Real exchange rates calculated using PPI } \\
\hline Country & From & To & Months (years) & From & To & Months (years) \\
\hline Bangladesh & $15 / 07 / 1993$ & $15 / 09 / 2011$ & $219(18.25)$ & $15 / 12 / 1971$ & $15 / 09 / 2011$ & $478(39.83)$ \\
\hline India & $15 / 01 / 1957$ & $15 / 09 / 2011$ & $657(54.75)$ & $15 / 01 / 1957$ & $15 / 10 / 2011$ & $658(54.83)$ \\
\hline Pakistan & $15 / 01 / 1957$ & $15 / 09 / 2011$ & $657(54.75)$ & $15 / 07 / 1961$ & $15 / 09 / 2011$ & $603(50.25)$ \\
\hline Sri Lanka & $15 / 01 / 1957$ & $15 / 05 / 2011$ & $653(54.42)$ & $15 / 01 / 1976$ & $15 / 02 / 2011$ & $422(35.17)$ \\
\hline
\end{tabular}

Next, the time-series properties of the real exchange rate are examined before the unit root test is conducted. The descriptive statistics of real exchange rate based on CPI and PPI are given in panels A and B, respectively, of Table 2. In panel A, for most of the data series, the mean and median values are not close, and the skewness parameter indicates nonsymmetric distribution. Further, the Jarque-Bera (JB) normality test rejects the approximately normal distribution assumption for each sample country's real exchange rate. The descriptive statistics of PPI data set in panel B also show that the real exchange rates of sample countries are not normally distributed.

Table 2: Descriptive Statistic of Real Exchange Rate

\begin{tabular}{l|c|c|c|c|c}
\hline & Mean & Median & Skewness & Kurtosis & Jarque-Bera \\
\hline \multicolumn{7}{l|}{ Panel A: Real exchange rates calculated using CPI } \\
\hline Bangladesh & 57.81646 & 60.06000 & -1.530740 & 4.778984 & 114.4041 \\
\hline India & 33.40993 & 34.05000 & -0.132256 & 1.803205 & 41.12504 \\
\hline Pakistan & 38.35932 & 38.07000 & 0.033913 & 1.624722 & 51.90269 \\
\hline Sri Lanka & 56.88115 & 59.27000 & 0.089988 & 1.549123 & 58.15607 \\
\hline Panel B: Real exchange rates calculated using PPI & & & \\
\hline Bangladesh & -13.03127 & -14.39080 & -0.630922 & 3.756308 & 43.10470 \\
\hline India & 38.23784 & 42.62000 & -0.279931 & 1.417662 & 77.23934 \\
\hline Pakistan & 46.12132 & 55.55000 & -0.813882 & 2.921280 & 66.72723 \\
\hline Sri Lanka & 77.12854 & 80.59750 & -0.425974 & 2.980731 & 12.76880 \\
\hline
\end{tabular}




\section{Stationarity test results}

The two sets of real exchange rates are calculated from Equation (2) with the use of CPI and PPI. In tables 3 to 6 , the unit root tests results are presented under panels A and B for real exchange rates using the two different price deflators, CPI and PPI, respectively. The empirical analysis starts with a discussion of the ADF and PP unit root test results, in which an assumption of no structural changes exists. The ADF and PP unit root runs on level (i.e. constant and trend) and first difference, and the results are shown in Table 3. Under panel A, for both ADF and PP tests, India and Pakistan significantly reject the null hypothesis of the unit root, whereas Bangladesh and Sri Lanka fail to reject the null hypothesis of the unit root. Under panel B, for both ADF and PP tests, Bangladesh and Pakistan reject the null hypothesis of the unit root at 5\% and 1\% levels of significance, respectively. By contrast, India and Sri Lanka fail to reject the null hypothesis of the unit root. The unit root test results are not only mixed across countries but are also inconsistent across data sets. In other words, we do not get a clear picture of stationarity for the real exchange rates of our sample countries.

Table 3: Unit Root Test without Structural Breaks

\begin{tabular}{|c|c|c|c|c|c|c|}
\hline \multicolumn{4}{|c|}{ ADF Test } & \multicolumn{3}{|c|}{ PP Test } \\
\hline & $\begin{array}{c}\text { Level } \\
\text { (constant and } \\
\text { trend) }\end{array}$ & $\begin{array}{l}\text { 1st Difference } \\
\text { (constant) }\end{array}$ & Result & $\begin{array}{c}\text { Level } \\
\text { (constant and } \\
\text { trend) }\end{array}$ & $\begin{array}{c}\text { 1st Difference } \\
\text { (constant) }\end{array}$ & Result \\
\hline \multicolumn{7}{|c|}{ Panel A: Real exchange rates calculated using CPI } \\
\hline Bangladesh & 0.407025 & $-10.17511^{* *}$ & $\mathrm{I}(1)$ & 0.901367 & $-9.976029 * *$ & $\mathrm{I}(1)$ \\
\hline India & $5.497959 * *$ & $-11.35414^{* *}$ & $\mathrm{I}(0)$ & $4.997744 * *$ & $-23.01690 * *$ & $\mathrm{I}(0)$ \\
\hline Pakistan & $8.411467 * *$ & $-6.903510 * *$ & $\mathrm{I}(0)$ & $8.472086 * *$ & $-24.90424 * *$ & $\mathrm{I}(0)$ \\
\hline Sri Lanka & 2.449390 & $-24.84375^{* *}$ & $\mathrm{I}(1)$ & 1.976174 & $-23.89521 * *$ & $\mathrm{I}(1)$ \\
\hline \multicolumn{7}{|c|}{ Panel B: Real exchange rates calculated using PPI } \\
\hline Bangladesh ${ }^{1}$ & $-3.804569 *$ & $-15.73562 * *$ & $\mathrm{I}(0)$ & $-3.804569 *$ & $-15.73088 * *$ & $\mathrm{I}(0)$ \\
\hline India & 0.760419 & $-25.19711^{* *}$ & $\mathrm{I}(1)$ & 0.857088 & $-25.20513^{* *}$ & $\mathrm{I}(1)$ \\
\hline Pakistan & $6.989455 * *$ & $-7.690420 * *$ & $\mathrm{I}(0)$ & $5.809139 * *$ & $-23.41526 * *$ & $\mathrm{I}(0)$ \\
\hline Sri Lanka & 1.707431 & $-11.13267 * *$ & $\mathrm{I}(1)$ & 1.184450 & $-19.96781^{* *}$ & $\mathrm{I}(1)$ \\
\hline
\end{tabular}

Next, the unit root test is performed by considering structural changes for the long period of the sample data series. The Zivot-Andrews model is used to detect one endogenous structural break for the unit root tests and the results are shown in Table 4. The last column shows that all countries fail to reject the null hypothesis of the unit root for both types of real exchange rate series in Panel $\mathrm{A}$ and $\mathrm{B}$, respectively. This finding means that the real exchange rates of all sample countries are nonstationary. According to Ben-David et al. (2003), Lumsdaine and Papell (1997) and Maddala and Kim (2003), these findings are biased due to loss of information if actually more than one break exists. 
Table 4: Unit Root Test with One Endogenous Structural Break: Zivot-Andrews Test

\begin{tabular}{|c|c|c|c|c|c|}
\hline & $\begin{array}{c}\text { Level } \\
\text { (constant and trend) }\end{array}$ & $\begin{array}{l}\text { Break Point } \\
\text { (level) }\end{array}$ & $\begin{array}{l}\text { 1st Difference } \\
\text { (constant) }\end{array}$ & $\begin{array}{c}\text { Break Point } \\
\text { (1st difference) }\end{array}$ & Result \\
\hline \multicolumn{6}{|c|}{ Panel A: Real exchange rates calculated using CPI } \\
\hline Bangladesh $^{1}$ & -4.615 & Dec 2005 & $-8.434 * * *$ & Aug 2006 & $\mathrm{I}(1)$ \\
\hline India & -1.840 & Dec 2001 & $-9.523 * * *$ & Mar 2003 & $\mathrm{I}(1)$ \\
\hline Pakistan & -2.106 & Sept 2000 & $-9.862 * * *$ & July 2001 & $\mathrm{I}(1)$ \\
\hline Sri Lanka & -4.084 & July 1998 & $-13.378 * * *$ & Nov 2002 & $\mathrm{I}(1)$ \\
\hline \multicolumn{6}{|c|}{ Panel B: Real exchange rates calculated using PPI } \\
\hline Bangladesh $^{1}$ & -5.004 & July 2002 & $-15.924 * * *$ & Dec 1984 & $\mathrm{I}(1)$ \\
\hline India & -2.487 & Apr 1988 & $-12.904 * * *$ & Sept 1972 & $\mathrm{I}(1)$ \\
\hline Pakistan & -1.384 & Mar 2004 & $-9.224 * * *$ & Jun 2001 & $\mathrm{I}(1)$ \\
\hline Sri Lanka & -3.943 & Apr 2005 & $-12.163^{* * *}$ & Nov 2005 & $\mathrm{I}(1)$ \\
\hline
\end{tabular}

Notes: $*$ and $* *$ denote $5 \%$ and $1 \%$ levels of significance, respectively. The $5 \%$ and $1 \%$ critical values in level with constant and trend are -5.08 and -5.57 , respectively and in $1^{\text {st }}$ difference with constant only are -4.80 and 5.43, respectively. Lag selection is automatic on the basis of T-Test. ${ }^{1}$ For Bangladesh, the MPI is used as proxy of discontinuous PPI series.

To address the unit root test results issue for the Zivot-Andrews model, the ClementeMontañes-Reyes test is employed. This test allows determining two endogenous structural breaks in the data series. Table 5 presents the test results of the IO approach, which allows gradual changes. The last column shows that all sample countries cannot reject the null hypothesis of the unit root for both real exchange rate series data.

Table 5: Unit Root Test with Two Endogenous Structural Breaks: Clemente-Montañés-Reyes Test (IO Model)

\begin{tabular}{|c|c|c|c|c|c|}
\hline & Min $t$ in Level & $\begin{array}{c}\text { Break Points } \\
\text { (Level) }\end{array}$ & $\begin{array}{l}\text { Min } t \text { in } 1^{\text {st }} \\
\text { Difference }\end{array}$ & $\begin{array}{l}\text { Break Points } \\
\text { (1st difference) }\end{array}$ & Result \\
\hline \multicolumn{6}{|c|}{ Panel A: Real exchange rates calculated using CPI } \\
\hline Bangladesh ${ }^{1}$ & -2.340 & $\begin{array}{l}\text { BP1= Apr } 2007 \\
\text { BP2= May } 2009\end{array}$ & $-5.524 *$ & $\begin{array}{l}\text { BP1= Apr } 2001 \\
\text { BP2= Feb } 2006\end{array}$ & $\mathrm{I}(1)$ \\
\hline India & -2.403 & $\begin{array}{l}\text { BP1= Jan } 1975 \\
\text { BP2= Apr } 2006\end{array}$ & $-6.658 *$ & $\begin{array}{l}\text { BP1= Feb } 1993 \\
\text { BP2= Sep } 2006\end{array}$ & $\mathrm{I}(1)$ \\
\hline Pakistan & -1.809 & $\begin{array}{l}\text { BP1= July } 1978 \\
\text { BP2= May } 2007\end{array}$ & $-5.500 *$ & $\begin{array}{l}\text { BP1= Apr } 1972 \\
\text { BP2= Aug } 2000\end{array}$ & $\mathrm{I}(1)$ \\
\hline Sri Lanka & -1.233 & $\begin{array}{l}\text { BP1= July } 1977 \\
\text { BP2= May } 1998\end{array}$ & $-9.964 *$ & $\begin{array}{l}\mathrm{BP} 1=\text { Apr } 1998 \\
\mathrm{BP} 2=\text { Sep } 1998\end{array}$ & $\mathrm{I}(1)$ \\
\hline \multicolumn{6}{|c|}{ Panel B: Real exchange rates calculated using PPI } \\
\hline Bangladesh ${ }^{1}$ & -5.408 & $\begin{array}{l}\text { BP1= Jun } 1984 \\
\text { BP2= Mar } 1985\end{array}$ & $-6.454 *$ & $\begin{array}{l}\mathrm{BP} 1=\text { Oct } 1984 \\
\mathrm{BP} 2=\text { Jun } 1985\end{array}$ & $\mathrm{I}(1)$ \\
\hline India & -2.936 & $\begin{array}{l}\text { BP1 }=\text { May } 1974 \\
\text { BP2 }=\text { Dec } 2000\end{array}$ & $-9.500 *$ & $\begin{array}{l}\text { BP1= Feb } 1993 \\
\text { BP2= Aug } 2008\end{array}$ & $\mathrm{I}(1)$ \\
\hline Pakistan & -2.134 & $\begin{array}{l}\text { BP1 }=\text { Mar } 1972 \\
\text { BP2= Apr } 2007\end{array}$ & $-5.923 *$ & $\begin{array}{l}\text { BP1= Apr } 1999 \\
\text { BP2=Apr } 2001\end{array}$ & $\mathrm{I}(1)$ \\
\hline Sri Lanka & -4.463 & $\begin{array}{l}\text { BP1= Apr } 1998 \\
\text { BP2=Apr } 2007\end{array}$ & $-8.052 *$ & $\begin{array}{l}\text { BP1= Apr } 1998 \\
\text { BP2= Sep } 1998\end{array}$ & $\mathrm{I}(1)$ \\
\hline
\end{tabular}

Notes: Min t is the minimum t-statistic calculated. BP1 and BP2 refer to the first and second break points, respectively. * denotes $5 \%$ level of significance. The $5 \%$ critical value for the IO model is -5.490 . ${ }^{1}$ For Bangladesh, the MPI is used as a proxy of discontinuous PPI series.

Finally, the Clemente-Montañes-Reyes test is conducted by allowing a sudden change in mean under the AO approach. The unit test results are shown in Table 6. The values in Column 1 are less than the critical value of 5.490 at 5\% level of significance for the two real exchange rate series. This result indicates that the real exchange rates of all sample countries 
are nonstationary. The unit root test results of the AO approach are consistent with those of the IO approach.

Table 6: Unit Root Test with Two Endogenous Structural Breaks: Clemente-Montañés-Reyes test (AO Model)

\begin{tabular}{|c|c|c|c|}
\hline \multicolumn{2}{|l|}{ Min $t$ in Level } & $\begin{array}{c}\text { Break Points } \\
\text { (Level) }\end{array}$ & $\begin{array}{c}\text { Min } t \text { in } \\
\text { 1st Difference }\end{array}$ \\
\hline \multicolumn{4}{|c|}{ Panel A: Real exchange rates calculated using CPI } \\
\hline Bangladesh $^{1}$ & -2.129 & $\begin{array}{l}\text { BP1= Oct } 2000 \\
\text { BP2 }=\text { Nov } 2007\end{array}$ & $-6.426 *$ \\
\hline India & -2.673 & $\begin{array}{l}\text { BP1 }=\text { May } 1980 \\
\text { BP2 }=\text { Jan } 2007\end{array}$ & $-6.241 *$ \\
\hline Pakistan & -3.038 & $\begin{array}{l}\text { BP1= July } 1982 \\
\text { BP2= Aug } 2008\end{array}$ & $-5.789 *$ \\
\hline Sri Lanka & -0.614 & $\begin{array}{l}\text { BP1= Dec } 1977 \\
\text { BP2= Nov } 1989\end{array}$ & $-6.031 *$ \\
\hline \multicolumn{4}{|c|}{ Panel B: Real exchange rates calculated using PPI } \\
\hline Bangladesh $^{1}$ & -3.721 & $\begin{array}{l}\text { BP1= Dec } 1984 \\
\text { BP2= Oct } 1985\end{array}$ & $-5.678 *$ \\
\hline India & -3.292 & $\begin{array}{l}\text { BP1= May } 1978 \\
\text { BP2= Jan } 2003\end{array}$ & $-6.181 *$ \\
\hline Pakistan & -3.397 & $\begin{array}{l}\text { BP1= Jun } 1979 \\
\text { BP2= Sep } 2008\end{array}$ & $-6.714^{*}$ \\
\hline Sri Lanka & -1.688 & $\begin{array}{l}\text { BP1= Mar } 1998 \\
\text { BP2= Mar } 2007\end{array}$ & $-7.423 *$ \\
\hline
\end{tabular}

Notes: Min t is the minimum t-statistic calculated. BP1 and BP2 refer to the first and second break points, respectively. * denotes $5 \%$ level of significance. The $5 \%$ critical value for the AO model is -5.490 . ${ }^{1}$ For Bangladesh, the MPI is used as a proxy of discontinuous PPI series.

\section{Conclusion}

Numerous documentations on the findings of nonlinearity in exchange rates have been added to the linear exchange rate study. Accordingly, a number of studies have conducted nonlinear unit root tests for the real exchange rates of South Asian countries. Some of these studies argued in favour of stationary real exchange rates, whereas others concluded the nonstationarity of real exchange rates. These studies considered the nonlinear property of the real exchange rate for the stationarity test. A major problem with these studies, however, is their failure to account the structural changes for long periods of the data series. This paper aims to investigate the stationarity of the real exchange rates of four major South Asian countries, namely, Bangladesh, India, Pakistan and Sri Lanka, by allowing both single and multiple endogenous structural breaks. Two sets of real exchange rates series are calculated, one deflated by CPI and the other by PPI for additional robustness checks of our results.

With no structural change assumption, the ADF and PP unit root test results are mixed. The presence of structural changes could be one of the main reasons for the mixed findings on real exchange rate stationarity. To resolve this issue, the Zivot-Andrews model is used to detect one endogenous structural break for unit root tests. The test results show that the real exchange rates of all sample countries are nonstationary. Ben-David et al. (2003), Lumsdaine and Papell (1997) and Maddala and Kim (2003), among others, argued that one endogenous structural break for unit root tests results is biased due to loss of information if more than one break exists. To address the unit root test results issue for the Zivot-Andrews model, the Clemente-Montañes-Reyes test is employed. The maximum two structural breaks are determined, and a gradual change (IO approach) and a sudden change in mean (AO approach) are allowed. For both approaches, all sample countries cannot reject the null 
hypothesis of the unit root on real exchange rates. This result is consistent with that of the Zivot-Andrews unit root test.

In summary, for major South Asian countries without structural break consideration, the unit root tests with neither linear assumption (e.g. the ADF and PP tests) nor nonlinear framework (e.g. the KPSS test) in the previous research, provide a concrete picture of real exchange rate stationarity. Meanwhile, both single and multiple endogenous structural break unit root tests strongly suggest that the real exchange rates of Bangladesh, India, Pakistan and Sri Lanka are all indistinguishable from I (1) process. This finding implies that the PPP does not hold for the South Asian region in the long run. This is because exchange rates of these countries against the U.S. dollar fail to adjust by the ratio of the foreign price level to the domestic price level. Thus our results imply that real exchange rate in the South Asian region has been permanently affected by a series of real shocks such as changes in consumption preferences, tariffs and shocks to terms of trade. One of the important policy implications of our results is that permanent trade imbalances may result due to non-holding of PPP in the long run. As a result, any finite movement, if any, towards an equilibrium position of balance of payments in the long run will be very slow. Moreover, there will be advantages for the arbitragers to earn risk-free money from commodity markets, which in turn may devalue South Asian real exchange rates (Noman \& Rahman 2010). Thus government intervention is needed to control for inflation and to maintain international competiveness in the long run (Dornbusch, 1988).

\section{References}

Adler, M \& Lehmann, B 1983, 'Deviations from purchasing parity in the long run', The Journal of Finance, vol. 38, pp. 1471-1483. http://dx.doi.org/10.1111/j.15406261.1983.tb03835.x

Ahmad, S \& Rashid, A 2008, 'Non-linear PPP in South Asia and China', Economics Bulletin, vol. 6, pp. 1-6.

Artus, JR 1978, 'Methods of Assessing the Long Run Equilibrium Value of an Exchange Rate', Journal of International Economics, vol. 8, pp. 277-99. http://dx.doi.org/10.1016/0022-1996(78)90024-7

Baum, CF, Barkoulas, JT \& Caglayan, M 2001, 'Nonlinear Adjustment to Purchasing Power Parity in the Post Bretton Woods Era', Journal of International Money and Finance, vol. 20, pp. 379-399. http://dx.doi.org/10.1016/S0261-5606(00)00043-7

Ben-David D, Lumsdaine, R, \& Papell, DH 2003, 'Unit root, postwar slowdowns and longrun growth: Evidence from two structural breaks’, Empirical Economics, vol. 28, pp. 303-319. http://dx.doi.org/10.1007/s001810200132

Bhattacharya, PS, Karayalcin, C \& Thomakos, D 2008, 'Exchange Rate PassThrough and Relative Prices: An Industry-Level Empirical Investigation', Journal of International Money and Finance, vol. 27, pp. 1135-1160. http://dx.doi.org/10.1016/j.jimonfin.2008.05.004

Chowdhury, I 2004, 'Purchasing Power Parity and the Real Exchange Rate in Bangladesh: A Nonlinear Analysis', Working Paper Series in Economics, no. 14, University of Cologne.

Clemente, J, Montañés, A,\& Reyes, M 1998, 'Testing for a unit root in variables with a double change in the mean', Economics Letters, vol. 59, pp. 175-182. http://dx.doi.org/10.1016/S0165-1765(98)00052-4

Corbae, D \& Ouliaris, S 1991, 'A Test of Long-run Purchasing Power Parity Allowing for Structural Breaks', Economic Record, vol. 67, pp. 26-33. http://dx.doi.org/10.1111/j.1475-4932.1990.tb02525.x 
Dickey, DA, \& Fuller, WA 1981, 'Likelihood ratio statistics for autoregressive time series with a unit root', Econometrica, vol. 49, pp. 1057-1072. http://dx.doi.org/10.2307/1912517

Dornbusch, R 1980, 'Exchange Rate Economics: Where Do We Stand?’, Brookings Papers, pp. 143-206.

Dornbusch, R 1988, 'Purchasing Power Parity', in Eatwell, J, Milgrave, M \& Newman, P (eds), The New Palgrave Dictionary of Economics, Stockton Press, New York, pp. 1075-85.

Edison, JH 1985, 'Purchasing power parity: A quantitative reassessment of the 1920s experience', Journal of International Money and Finance, vol. 4, pp. 361-372. http://dx.doi.org/10.1016/0261-5606(85)90015-4

Engel, C 2002, 'The Responsiveness of Consumer Prices to Exchange Rates and the Implication for Exchange-Rate Policy: A Survey of A Few Recent New Open-Economy Macro Models', Working Paper of the National Bureau of Economic Research, No. 8725.

Frenkel, JA 1981, 'Flexible Exchange Rates, Prices and the Role of News: Lessons from the 1970’s’, Journal of Political Economy, vol. 89, pp. 665-705. http://dx.doi.org/10.1086/260998

Genberg, H 1978, 'Purchasing Power Parity under Fixed and Flexible Exchange Rates', Journal of International Economics, vol. 8, pp. 247-76. http://dx.doi.org/10.1016/00221996(78)90023-5

Hakkio, CS 1984, 'A re-examination of purchasing power parity: A multi-country and multiperiod study', Journal of International Economics, vol 17, pp. 265-277. http://dx.doi.org/10.1016/0022-1996(84)90023-0

Kapetanios, G, Shin, Y \& Snell, A 2003, 'Testing for a Unit Root in the Nonlinear STAR Framework', Journal of Econometrics, vol. 112, pp. 359-379. http://dx.doi.org/10.1016/S0304-4076(02)00202-6

Kravis, IB, Kennessey, Z, Heston, AW \& Summers, R 1975, A System of International Comparisons of Gross Product and Purchasing Power, Johns Hopkins University Press, Baltimore, MD.

Kravis, IB, Kennessey, Z, Heston, AW, Summers, R \& Lipsey, RE 1978, 'Price Behavior in the Light of Balance of Payments Theories', Journal of International Economics, vol. 8, pp. 193-246. http://dx.doi.org/10.1016/0022-1996(78)90022-3

Liew, VKS, Chong, TTL \& Lim, KP, 2003, 'The Inadequacy of Linear Autoregressive Model for Real Exchange Rates: Empirical Evidence from Asian Economies', Applied Economics, vol. 35, pp. 1387-1392. http://dx.doi.org/10.1080/0003684032000129750

Liew, VKS, 2004, 'Nonlinear Adjustment of ASEAN-5 Real Exchange Rates: Symmetrical or Asymmetrical?’ Economics Bulletin, vol. 6, pp.1-8.

Liew, VKS, Baharumshah, AZ \& Chong TTL 2004, 'Are Asian Real Exchange Rates Stationary?’ Economics Letters, vol. 83, pp. 313-316. http://dx.doi.org/10.1016/j.econlet.2003.10.021

Lumsdaine, RL \& Papell, DH 1997, 'Multiple Trend Breaks and the Unit Root Hypothesis', Review of Economics and Statistics, vol. 79, pp. 212-218. http://dx.doi.org/10.1162/003465397556791

Luukkonen, R, Saikkonen, P \& Teräsvirta, T 1988, 'Testing Linearity against Smooth Transition Autoregressive Models’, Biometrika, vol. 75, pp. 491-499. http://dx.doi.org/10.1093/biomet/75.3.491

Maddala, GS \& Kim, IM 2003, Unit Root, Cointegration and Structural Change, 5th edn, Cambridge University Press, UK. 
Meese, RA, \& Rogoff, K 1988, 'Was it real? The Exchange Rate-Interest Differential Relation over the Modern Floating-Rate Period', Journal of Finance, vol. 43, pp. 93348. http://dx.doi.org/10.1111/j.1540-6261.1988.tb02613.x

Michael, P, Nobay, AR \& Peel, DA 1997, 'Transaction Costs and Nonlinear Adjustment in Real Exchange Rates: An Empirical Investigation', Journal of Political Economy, vol. 105, pp. 862-879. http://dx.doi.org/10.1086/262096

Noman, AM \& Rahman, MZ 2010, 'Stationarity of South Asian real exchange rates under Exponential Star (ESTAR) framework', Journal of Developing Areas, vol. 43, pp. 4150. http://dx.doi.org/10.1353/jda.0.0068

Obstfeld, M 2002, Exchange Rates and Adjustment: Perspectives from the New Open Economy Macroeconomics, University of California, Berkley.

Officer, LH 1976, 'The Purchasing Power Parity Theory of Exchange Rates: A Review Article' IMF Staff Papers, vol. 23, pp. 1-60. http://dx.doi.org/10.2307/3866665

Perron, P 1989, 'The great crash, the oil price shock, and the unit root hypothesis', Econometrica, vol. 57, pp. 1361-1401. http://dx.doi.org/10.2307/1913712

Phillips, PCB \& Perron, P 1988, 'Testing for a Unit Root in Time Series Regression', Biometrika, vol. 75, pp. 335-346. http://dx.doi.org/10.1093/biomet/75.2.335

Rogoff, K 1996, ‘The Purchasing Power Parity Puzzle', Journal of Economic Literature, vol. 34, pp. 647-668.

Roll, R 1979, 'Violations of Purchasing Power Parity and their Implications for Efficient International Commodity Markets', in Sarnat, M \& Szego, GP (eds), International Finance and Trade, Vol. 1, Ballinger, Cambridge, Massachusetts.

Saikkonen, P \& Luukonen, R 1988, 'Lagrange Multiplier Tests for Testing Non-Linearities in Time Series Models', Scandinavian Journal of Statistics, vol. 15, pp. 55-68.

Sarantis, N 1999, 'Modelling Nonlinearities in Effective Exchange Rates', Journal of International Money and Finance, vol. 18, pp. 27-45. http://dx.doi.org/10.1016/S0261$\underline{5606(98) 00045-X}$

Stockman, AC 1980, 'A Theory of Exchange Rate Determination', Journal of Political Economy, vol. 88, pp. 673-98. http://dx.doi.org/10.1086/260897

Taylor, MP, Peel, DA \& Sarno, L 2001, 'Nonlinear Mean-Reversion in Real Exchange Rates: Toward a Solution to the Purchasing Power Parity Puzzles', International Economic Review, vol. 42, pp. 1015-1042. http://dx.doi.org/10.1111/1468-2354.00144

Zivot, E \& Andrews, DWK 1992, 'Further evidence on the great crash, the oil price shock and the unit root Hypothesis', Journal of Business and Economic Statistics, vol. 10, pp. 251-270. 